\title{
Retrospection: The First Hundred Years of North Carolina's Libraries 1960
}

\author{
Elizabeth H. Smith*
}

$\mathrm{T}$ This fifth in a series of articles about North Carolina's libraries begins in 1946 before construction resumed after World War II. During the next fifteen years, new library buildings and renovations were completed at a pace never before seen in North Carolina, which allowed libraries to offer new services to meet the demands of more library users. A selfsurvey of libraries in the nine southeastern states looked at the good and bad in libraries in 1946-1947 and found that State Aid to Public Libraries, which began in 1941, was part of the reason that a larger percent of North Carolina's population had access to libraries than in any of the other states surveyed. ${ }^{1}$

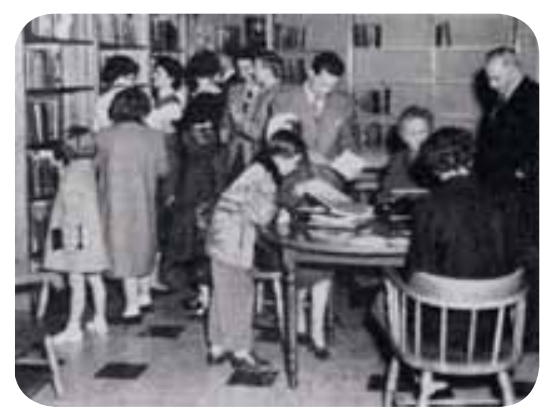

Greensboro's First Baptist Church Library became part a new innovation in special libraries in 1952 when it occupied an 800square-foot room near the sanctuary of the $\$ 1.2$ million church. ${ }^{2}$

In 1954, North Carolina Libraries recognized NCLA's Golden Anniversary with the publication of historical articles about libraries in North Carolina and NCLA founders were honored by the Durham High School Library Club. ${ }^{3}$

\section{Public Libraries}

Marjorie Beal, Secretary and Director of the North Carolina Library Commission, said of the findings of the survey of libraries in the Southeast: "North Carolina has a good spread of county and public library services, now is needed an enrichment of that service." ${ }^{\prime 4}$ Among the enrichments needed were additional trained librarians, better book collections and buildings, additional services, and bookmobiles for every county. Library service for Negroes was showing progress by the late 1940s with increased support from State Aid to Public Libraries, the demand for more books from the readers, and the appointment of a part-time Negro Supervisor of Rural Libraries in 1946. ${ }^{6}$ By 1950, North Carolina had more bookmobiles than any other state, but there was still a shortage of trained personnel to staff the trucks and book collections needed to be improved. ${ }^{7}$

\section{Public Library Statistics}

\begin{tabular}{|lcc|}
\hline & $\mathbf{1 9 4 7}$ & $\mathbf{1 9 6 0}$ \\
Population & $3,215,710^{*}$ & $4,531,834^{* *}$ \\
Volumes & $1,488,411$ & $3,679,531$ \\
Bookmobiles & $71^{\dagger}$ & $106^{\dagger \dagger}$ \\
Current Income & $1,214,098.40$ & $3,363,771.98$ \\
Per Capita Income & .38 & $.74^{8}$ \\
$* 1940$ & & \\
$* * 1960$ projected & & \\
$\dagger$ serving 81 counties & $\dagger$ serving 94 counties & \\
\hline
\end{tabular}

In an effort to improve library services, the Governor's Study Commission appointed in 1953 recommended the merger of the State Library and the North Carolina Library Commission, which was effective July 1, 1956. With the merger, the first issue of the Biennial Report of the North Carolina State Library replaced the Report of the North Carolina Library Commission. The State Library was charged with two major functions: 1) providing library service to state officials and agencies and to citizens through a network of public libraries and 2) overseeing library development throughout the state. ${ }^{9}$

The year 1956 was an important time for North Carolina public libraries with the reorganization of the State Library, which became a depository for North Carolina state documents and began to loan films to local libraries that wanted to schedule film

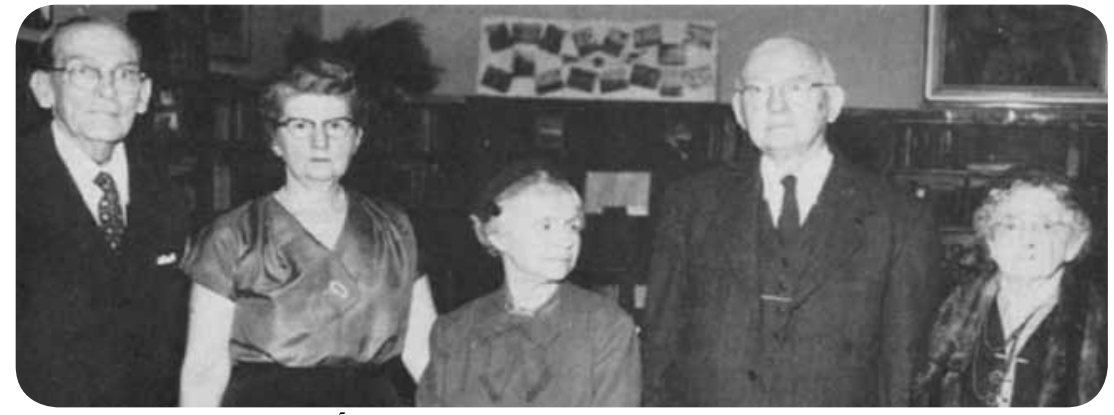

Photo by Harold Moore ${ }^{5}$
Left to right: Dr. J.P. Breedlove, NCLA Founder and former Duke University librarian; Miss Florine Lewter, first director of Durham City School libraries; Miss Clara Crawford, librarian of the Durham Public Library for the past 32 years; Dr. Louis R. Wilson, NCLA Founder and former University of North Carolina librarian; and Mrs. Lillian B. Griggs, formerly librarian of the Durham Public Library, Secretary and Director of the North Carolina Library Commission, and Woman's College of Duke University librarian. Mrs. Griggs died less than a month after the picture was made.

* Professor Emeritus, East Carolina University, Greenville, NC 


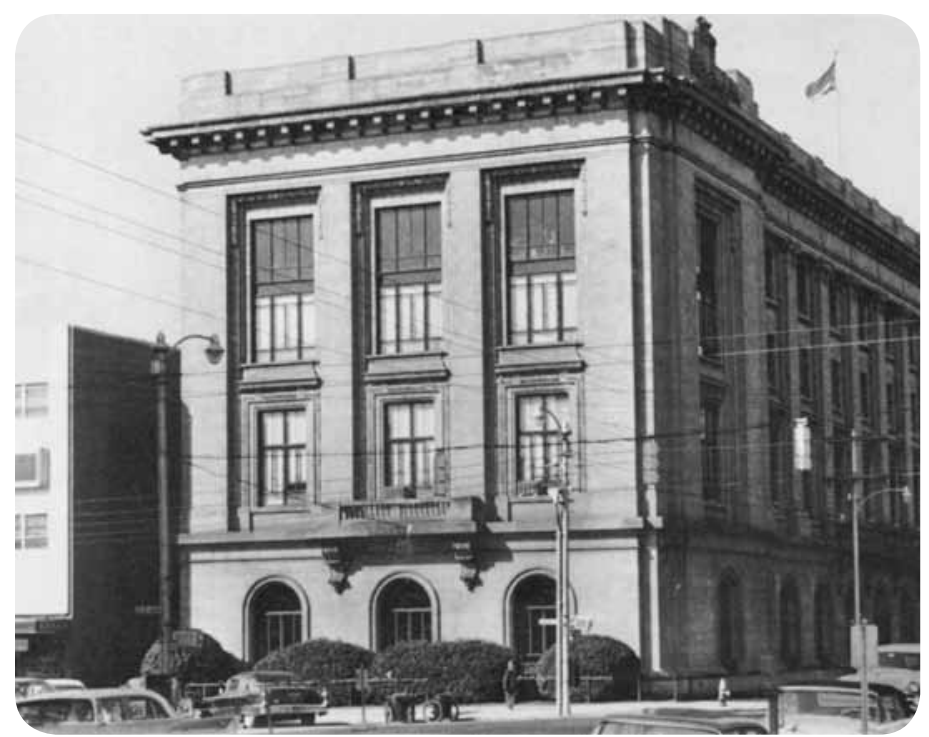

State Library Building ${ }^{11}$

programs. ${ }^{10}$ In 1957, the State Library partnered with the UNC library school to present the first workshop in the nation on the new ALA public library standards that had been published in $1956 .{ }^{12}$

Library facilities increased in quality and quantity in the $1950 \mathrm{~s}$. By 1958, 67 towns had new or improved library facilities, 44 of which had been designed as libraries. ${ }^{13}$ Construction for public libraries included the following:

\section{0}

New buildings were opened at Scotland County, Benson, Biscoe, and Swan Quarter; additions to libraries were made in Southern Pines, Smithfield; and Northampton County. Raleigh's Richard B. Harrison Library and the Robersonville library moved into renovated quarters. ${ }^{14}$

\section{2-1953}

New library buildings occupied in 1952-1953 included Washington'sGeorgeH.andLauraE.BrownLibrary,Cumberland County, Rowan County in Salisbury, Faith, Asheboro's Randolph Negro Branch, Onslow County, Robbinsville, Hillsborough's Orange County Negro Public Library, and Belhaven Public Library. Additions and renovations were completed at Rockingham County, Asheville's Pack Memorial, Warren County, Anson County, and Wadesboro. Asheville's new Haywood Road Branch, which opened in June 1953, was the first branch library to open in a building constructed as a library and had the first electric charging machine. The local newspaper described Winston-Salem's new public library as a dream come true when it opened in March 1953. The Randleman Public Library moved into permanent quarters in October 1953 after being housed in several temporary locations. ${ }^{15}$ Programs featuring music became a new library service throughout the state, and in 1953 the library in Kinston installed the first highfidelity system in any public library in North Carolina. ${ }^{16}$

\section{4}

By 1954, libraries were cooperating with community organizations to expand library services in towns and in special areas like hospitals and prisons. Burlington's May Memorial
Library opened a new Children's and Young People's Department in November 1954. Several libraries moved into new quarters in 1954: Union County in Monroe, Davie County in Mocksville, East Winston Branch in Winston-Salem, High Point, Farmville, Canton, and Haywood Road Branch in Asheville. ${ }^{17}$

\section{5}

The following libraries opened during 1955: Caswell County Confederate Memorial Library in Yanceyville, Dallas Public in Gaston County, Fayetteville's Gillespie Street Branch, Iredell County, Surry County in Dobson, China Grove in Rowan County, and Edgecombe Memorial in Tarboro. ${ }^{18}$

\section{6-1958}

The following libraries were opened between 1956 and 1958: Caldwell County, Pilot Mountain, Thomasville, Lincoln Heights in Laurinburg, Washington County in Plymouth, Bridger Memorial in Bladenboro, Harnett County in Lillington, Transylvania County in Brevard, Swannanoa, Pilot Mountain, Spruce Pine, and Chapel Hill. Branches were opened in Angier, Apex, Creedmoor, Currituck, East Laurinburg, Hatteras, Havelock, Kernersville, Lucama, Stantonsburg, Newport, and Avery County. ${ }^{19}$

\section{9-1960}

Libraries that opened in 1959-1960 included Gaston County (main library and five branches), Alleghany County, Haywood County, Burgaw, Carthage, Columbia, Denton, Dunn, Gibsonville, Rockingham, Spindale, Yadkinville, Bladenboro, Williamston, Grifton, Columbus County, North Asheville Branch, High Point's Washington Street Branch, and McGirt's Road Branch in Laurinburg. ${ }^{20}$

The federal Library Services Act, which was introduced on the House Floor by NC Representative Graham Barden and signed into law on June 19, 1956, provided money for libraries in each state for five years. The North Carolina Plan included ways to provide library services to rural and small-town citizens and to the six counties that did not have library service. ${ }^{21}$ This federal funding resulted in tremendous growth for developing library systems.

\section{School Libraries}

The Superintendent of Public Instruction's Biennial Report from 1946-1948 through 1950-1952 included the same introductory paragraph on school libraries:

School libraries continue to grow in number, size, and usefulness. The philosophy of library service is rapidly changing to include not only books but also audiovisual materials, thus making the libraries real materials centers. It has been the librarian's responsibility to locate needed films, recordings, filmstrips and like material, but now many libraries are housing and organizing this information, thus resulting in a closer integrated program of library service and a more enriched curriculum. ${ }^{22}$

The need for school library personnel was crucial during the tremendous growth of libraries in the 1950s, but support for libraries continued to come only from local money or textbook 
rental fees until the $1960 \mathrm{~s}$. Some schools met the need for library personnel by assigning library staff to work at several schools, by hiring library supervisors to work with teacherlibrarians in some school systems, or by hiring librarians with funds allotted for classroom teachers. In the 1959-1961 budget request, the Superintendent of Public Instruction for the first time recommended funding for library personnel to oversee the more than five million school library books in North Carolina. Trained library personnel were encouraged to relate library materials to the curriculum, thus improving the education of all students. ${ }^{23}$ The State Department of Public Instruction gave additional support to school library personnel with Publication No. 257, "Planning and Equipping the School Library."24

\section{School Library Collections, Circulations, Personnel, and Expenditures}

\begin{tabular}{|lcc|}
\hline \multicolumn{1}{|l}{} & $\mathbf{1 9 4 4 - 1 9 4 5}$ & $\mathbf{1 9 5 9 - 1 9 6 0}$ \\
\hline Library books owned & $3,197,933$ & $6,409,323$ \\
\hline Volumes per pupil & 4.2 & 5.98 \\
Total circulation & $9,838,935$ & $25,272,967$ \\
Average circulations per pupil & 14.29 & 22.85 \\
$\begin{array}{l}\text { Personnel with some } \\
\text { library training (full-time) }\end{array}$ & 121 & 558 \\
$\begin{array}{l}\text { Total expenditures for } \\
\text { school libraries }\end{array}$ & $\$ 443,199.66$ & $\$ 2,056,112.86$ \\
$\begin{array}{l}\text { Average expenditures } \\
\text { per pupil }\end{array}$ & .64 & $1.92^{25}$ \\
\hline
\end{tabular}

The 1958 National Defense Education Act (NDEA), which provided funding at all levels of public and private education, introduced a decade of tremendous growth for school libraries and media centers. This growth was evident almost immediately when expenditures for school libraries increased by approximately 20 percent from 1959 to $1960 .^{26}$

\section{University and College Libraries}

University and college libraries met the challenge of post-war enrollment increases with a construction boom that gave many schools new library buildings and provided space for additional services and staff. Building programs in progress in the late 1930s, which were put on hold during the war, were again in full swing by the 1950 s.

\section{9}

Duke University doubled the size of its library in 1949 with an addition to its 1930 building. ${ }^{27}$

\section{0}

Guilford College dedicated a $\$ 100,000$ library addition November 10, 1950. Greensboro College occupied the new James Addison Jones Library in the summer of 1950. Woman's College moved into a new $\$ 1.2$ million library in $1950 .{ }^{28}$

\section{1}

Libraries completed during 1951 included Pembroke, UNC Law School, and North Carolina College at Durham. ${ }^{29}$

\section{2}

The $\$ 1.6$ million addition to the main UNC library, which was dedicated April 18, 1952, was later named for Dr. Louis Round Wilson. ${ }^{30}$ Other libraries completed in 1952 included Atlantic Christian College, Barber-Scotia College, Gardner-Webb, a Physics-Mathematics Library at Duke, Fayetteville State Teachers College, and Warren Wilson College at Swannonoa. ${ }^{31}$

\section{3}

Western Carolina University's construction boom in the 1950s included a library building, which replaced the facility that had been in the Joyner Building since $1930 .^{32}$ The new library included facilities for students and townspeople as well as a cultural center for the region. Catawba College's CorriherLinn-Black Library opened in November $1953 .{ }^{33}$

\section{4}

The opening of the new $\$ 1$ million Joyner Library at East Carolina College on June 7, 1954, provided additional space for the collection and for services required by post-war enrollment increases. The Alison B. Stirling Library at Lees-McRae College opened November $1,1954 .^{34}$

\section{5}

At Mars Hill College, an anonymous donor gave money for a library with the understanding that the college would erect another building. The library opened in 1955 along with a men's dormitory. ${ }^{35}$ The million-dollar Bluford Library at North Carolina A\&T College opened in Greensboro in June 1955. NC State College in Raleigh dedicated the new \$1.2 million D.H. Hill Library on March 12, 1955. The Wake Forest College Library, which opened in 1955, was one of the first buildings constructed on the new campus at Winston-Salem. ${ }^{36}$

\section{Conclusion}

The period from 1946 to 1960 was a time of recovery for education after World War II that saw an explosion of library buildings and services. Following the recovery period, the 1960s was a time of increased funding and growth in libraries, especially in public schools where curriculum changes placed additional responsibilities on libraries. 


\section{References}

${ }^{1}$ North Carolina Library Commission Twentieth Report for the Biennium 1946-1948, 6.

${ }^{2}$ North Carolina Libraries 11:2 (January 1953): 22.

${ }^{3}$ North Carolina Libraries 13:4 (June 1955) Charles M. Adams. "The College Library in North Carolina, 1904-1954, 8-10; Elizabeth House Hughey. "Public Libraries in North Carolina," 11-16; Mary Peacock Douglas "School Libraries in North Carolina," 17-22.

${ }^{4}$ North Carolina Libraries 7:1 (March 1948): 5.

${ }^{5}$ North Carolina Libraries 13:4 (June 1955): 111.

${ }^{6}$ North Carolina Library Commission Twentieth Report for the Biennium 1946-1948, 11.

${ }^{7}$ North Carolina Library Commission Twenty-First Report for the Biennium 1948-1950, 12.

${ }^{8}$ North Carolina Library Commission Twentieth Report for the Biennium 1946-1948, 8, 18-19; Statistics of North Carolina Public Libraries, University and College Libraries, Special Libraries 1959-1960. Raleigh, North Carolina State Library, 1960, 16.

${ }^{9}$ North Carolina State Library Second Biennial Report 19581960, front.

${ }^{10}$ North Carolina State Library First Biennial Report 1956-1958, $12,14$.

${ }^{11}$ North Carolina Libraries 15:2 (January 1957): 31.

${ }^{12}$ North Carolina State Library First Biennial Report 1956-1958, 20.

${ }^{13}$ Ibid., 19-20.

${ }^{14}$ North Carolina Libraries 9:3 (February 1951): 3-4.

${ }^{15}$ North Carolina Library Commission Twenty-Third Report for the Biennium 1952-1954, 26; North Carolina Library Commission Twenty-Fourth Report for the Biennium 1954-1956, 4; North Carolina Libraries 11:3 (March 1953): 42-43; 11:4 (May 1953): 62; 12:1 (October 1953): 2,18.

${ }^{16}$ North Carolina Library Commission Twenty-Third Report for the Biennium 1952-1954, 9.

${ }^{17}$ North Carolina Library Commission Twenty-Fourth Report for the Biennium 1954-1956, 4; North Carolina Library Commission Twenty-Third Report for the Biennium 1952-1954, 26.

${ }^{18}$ Ibid, 4-5.

${ }^{19}$ North Carolina Libraries 17:1 (October 1958): 31-37; North Carolina Library Commission Twenty-Fourth Report for the Biennium 1954-1956, 6.

${ }^{20}$ North Carolina State Library Second Biennial Report 19581960, 27.

${ }^{21}$ North Carolina Library Commission Twenty-Fourth Report for the Biennium 1954-1956, 12; North Carolina Libraries 15:2 (January 1957): 44.

${ }^{22}$ Biennial Report of the Superintendent of Public Instruction of North Carolina, 1946-1948; 65; 1948-1950, 58; 1950-1952, 7273.

${ }^{23}$ Biennial Report of the Superintendent of Public Instruction of North Carolina, 1956-1958, 82.

${ }^{24}$ Biennial Report of the Superintendent of Public Instruction of North Carolina, 1946-1948, 66-67; 1956-1958, 69-70.

${ }^{25}$ Biennial Report of the Superintendent of Public Instruction of North Carolina, 1960-1962, 79-80.

${ }^{26}$ Biennial Report of the Superintendent of Public Instruction of North Carolina, 1958-1960. 79.
${ }^{27}$ North Carolina Libraries 8:1 (March 1949): 4.

${ }^{28}$ North Carolina Libraries 8:1 (March 1949): 4-5; 9:2 (November 1950): 5 .

${ }^{29}$ North Carolina Libraries 11:1 (October 1952): 46.

${ }^{30}$ North Carolina Libraries 10:3 (April 1952): 35; 14:2 (February 1956): 120

${ }^{31}$ North Carolina Libraries 11:1 (October 1952): 46-47; 14:2 (February 1956): 120; North Carolina Library Commission Twenty-Third Report for the Biennium 1952-1954, 28.

${ }^{32}$ Curtis W. Wood and H. Tyler Blethen. The Illustrated History of Western Carolina University. Cullowhee: Western Carolina University, 1989,128, 133)

${ }^{33}$ North Carolina Libraries 11:3 (March 1953): 49; 12:3 (April 1954): 53.

${ }^{34}$ North Carolina Libraries 13:2 (February 1955): 43; North Carolina Library Commission Twenty-Fourth Report for the Biennium 1954-1956, 6.

${ }^{35}$ John Angus McLeod. From These Stones: Mars Hill College, 1856-1968. (Mars Hill: Mars Hill College, 1968). 260-61.

${ }^{36}$ North Carolina Libraries 14:4 (June 1956): 5; North Carolina Library Commission Twenty-Fourth Report for the Biennium 1954-1956, 6; North Carolina Libraries 11:3 (March 1953): 66.

\section{Selected Bibliography}

Biennial Reports of the Superintendent of Public Instruction of North Carolina..., 1946-1948, 1948-1950, 1950-1952, 19561958, 1958-1960, 1960-1962. Raleigh, Department of Public Instruction.

McLeod, John Angus. From These Stones: Mars Hill College, 1856-1968. (Mars Hill: Mars Hill College, 1968).

North Carolina Libraries. 7:1 (March 1948): 5; 8:1 (March 1949): 4-5; 9:2 (November 1950): 5; 9:3 (February 1951) 3-4; 10:3 (April 1952): 35; 11:1 (October 1952): 46-47; 11:2 (January 1953): 22; 11:3 (March 1953): 42-43; 49, 66; 11:4 (May 1953): 62; 12:1 (October 1953): 2,18; 12:3 (April 1954): 53; 13:2 (February 1955): 43; 13:4 June 1955; 14:2 (February 1956): 120; 14:4 (June 1956): 5; 15:2 (January 1957): 31, 44; 17:1 (October 1958): 3137.

North Carolina Library Commission Reports. 1946-1948; 19481950; 1952-1954; 1954-1956. Raleigh, North Carolina Library Commission.

North Carolina State Library Biennial Reports 1956-1958, 19581960. Raleigh: North Carolina State Library.

Statistics of North Carolina Public Libraries, University and College Libraries, Special Libraries 1959-1960. Raleigh: North Carolina State Library, 1960.

Wood, Curtis W., and H. Tyler Blethen. The Illustrated History of Western Carolina University. Cullowhee: Western Carolina University, 1989. 